\title{
A study about the young consumers' consumption behaviors of street foods
}

\author{
Um estudo sobre o comportamento de consumo \\ dos jovens consumidores de alimentos de rua
}

Nevin Sanlier ${ }^{1}$

Aybuke Ceyhun Sezgin ${ }^{2}$

Gulsah Sahin ${ }^{1}$

Emine Yassibas ${ }^{1}$
${ }^{1}$ Department of Nutrition and Dietetics, Faculty of Health Sciences, Gazi University. Rektörlüğü Teknik okulları, 06560 Yenimahalle Besevler. Ankara Turkey.ntekgul@ gazi.edu.tr

${ }^{2}$ Department of

Gastronomy and Culinary Arts, Faculty of Tourism,

Gazi University. Ankara

Turkey.
Abstract As in almost every country in the world, street foods are frequently used in Turkey. To determine the preferences for these foods, a questionnaire was given to 847 individuals constituted by randomly selected high school and university students. Of the participants, $43.4 \%$ were male and $56.6 \%$ were female; the majority of them were between 19 and 22 years of age. It was found that $40.1 \%$ of the young people ate street food 2-3 times per week, whereas $23.3 \%$ were found to eat it every day. Turkish bagels, döner, boiled corn in a cup and toast are most preferred street foods. A statistically significant negative correlations were found between consumption preference scores and education, gender, and age. Although consumers know that street foods can cause contamination with microorganisms, that sellers do not pay attention to hygiene, and that these foods are raw or not cooked well, they prefer because of their cheapness, deliciousness, variety and fast service. Street foods are widely consumed in Turkish young students and because of preventing food poisoning, they should be educated about food hygiene and safety. Also, educating vendors in personal hygiene and good manufacture practice can minimize contamination risk. Key words Youth, Street food, Food preference
Resumo Alimentos de rua são frequentemente consumidos na Turquia como em quase todos os países do mundo. Foi aplicado um questionário para 847 indivíduos constituídos por estudantes de nível médio e superior que foram aleatoriamente selecionados. Dos participantes, 43,4\% eram do sexo masculino e 56,6\% do feminino; a maioria deles tinha entre 19 e 22 anos de idade. Foi constatado que 40,1\% dos jovens comem alimentos de rua 2-3 vezes por semana, enquanto 23,3\% todos os dias. Bagel turco döner, milho cozido em um copo e pão torrado são os alimentos de rua mais preferidos. A correlação negativa estatisticamente significativa foi encontrada entre as pontuações de preferências de consumo e educação, gênero e idade. Embora os consumidores saibam que os alimentos de rua podem causar contaminação com microrganismos, pois os vendedores não prestam atenção à higiene, $e$ que estes alimentos são crus ou mal cozidos, eles preferem por causa de seus custos baratos, o seu gosto, a variedade e o serviço rápido. Alimentos de rua são amplamente consumidos por jovens e estudantes turcos e para prevenir a intoxicação alimentar, eles devem ser educados sobre higiene e segurança alimentar. Além disso, educar fornecedores sobre higiene pessoal e boas práticas de fabricação podem minimizar o risco de contaminação. Palavras-chave Juventude, Alimentos de rua, Preferência alimentar 


\section{Introduction}

Nowadays, as in many fields of life, globalisation has caused differences in people's food consumption habits. In developing countries out-of-home consumption of foods and beverages is rising and causing differences in consumption styles ${ }^{1,2}$. Variable social profiles and the intensive participation of women in working life have caused observable changes in countries' economies and this has been reflected in food and beverage culture ${ }^{3,4}$. Accordingly, in recent years people in developing countries have spent most of their disposable income on food consumption, which has turned street foods into alternative sources of nutrition $^{2,5-7}$. Street foods are foods and beverages that are sold in the street and other open public spaces and that are ready to consume, without the need for any processing or preparation ${ }^{8}$. Street foods are sold in places where sometimes people briefly gather (on street corners, at interchanges, subway station entrances/exits, crossroads etc.) ${ }^{9}$.

Studies have shown that 2.5 billion people consume street food around the world ${ }^{8,10}$. This prevalent consumption raises the importance of food safety and its relation to health ${ }^{11}$. There are many epidemiological studies about relation of street food and diseases, because of lack of knowledge about hygiene, and food safety of street food seller's and the overabundance of pathogenic bacteria in street food samples ${ }^{12-14}$. In many countries around the world, especially in Africa, Asia, and Latin America, it has been found that street foods carry harmful pathogens and cause serious foodborne diseases ${ }^{12,15-23}$.

It is thought that the places where street food are prepared, sold, and consumed provide appropriate conditions for contamination ${ }^{13}$. The poor hygiene practices of food sellers and negative environmental conditions such as problems with the supply of clean drinking water and the disposal of waste increase food safety hazards, which is an important public health issue $e^{8,14,24,25}$. Food safety is highly important for developed and developing countries. In today's world, millions of people catch diseases originated from food sources and thousands of deaths occur ${ }^{26}$. Therefore, an increase in food poisoning due to the consumption of street food is seen as a risk $^{27}$. The contamination of foods with hazardous microorganisms such as E. coli, Salmonella typhimurium, Pseudomonas sp., Staphylococcus aureus, and Proteus in the food preparation, storage, and service stages can cause detrimental health consequences ${ }^{28-31}$. While diarrheal diseases caused by microbial pathogens originating from food sources are frequently seen both in developed and developing countries, it is reported that approximately 1.9 million people die from this disease around the world every year ${ }^{32}$. Street foods were responsible for 691 food poisoning outbreaks and 49 deaths from 1983 to 1992 in China ${ }^{33}$. Approximately 30 million people in Bangladesh have had a foodborne disease and these diseases result from flies and other organisms which can act as a source of pathogens for most food sold in the street ${ }^{27}$. According to The Ministry of Health of Turkey (2006), 23.901 Salmonella typhii infection, 429 Salmonella paratyphii infection, 21.068 dysenteria infection and 8824 Hepatitis A occurred in Turkey in $2004^{34}$. It was found that from past till today, the number of instances notified regarding food intoxications originating from E.coli O157H7 kept on increasing. Increase in global trade, traveling, changes in consumption of modern food, influence of modern life styles, and changes in food consumption have all caused new pathogens to form ${ }^{27}$. In many countries besides the fact that street food is not reliable, it is seen that they also carry diseases originating from food sources ${ }^{12,16,20,21,35}$. Although street foods carry health risks, they are good food alternatives for students and also offer people with low incomes and those working in small businesses a chance to meet their nutritional need $\mathrm{s}^{36,37}$.

Widespread urbanisation and population growth in some countries in recent years has in part driven the development of the illegal street food $\operatorname{sector}^{2,23}$. Although the FAO and WHO determine international rules according to feasibility studies to ensure the safety of foods sold and consumed in the street ${ }^{3}$, in most countries the sale of street food is an unrecorded and illegal market ${ }^{7,38}$. Studies have shown that in most countries' policies there is no legal arrangement for food safety or the sale of street food ${ }^{13,23}$. The preparation and sale of food has become an area of self-employment for those that have little or no educated, unemployed, and having financial difficulties in urban areas, as the number of people buying from this sector is considerable ${ }^{8}$.

The consumption of street food in Turkey is parallel to in many countries around the world. Some kind of street food can be seen almost everywhere in Turkey. Food and beverages such as çiğ köfte (steak tartare a la turca), gözleme (pancakes), Turkish bagels, pastries, kokoreç (grilled sheep intestine), meatball sandwiches, kebab, döner, pea meal pilav, mussels, boiled corn 
in a cup, boza, chestnuts, sahlep, liquorice, macun (gum-like candy) and cotton candy, wafers, candied apples, ice cream, etc. are sold in local businesses after being prepared and cooked in unsuitable conditions ${ }^{39,40}$. Street food is preferred by young people because of its cheapness, availability, variety, etc. There are some studies conducted in Turkey. It was determined that students prefered meatballs in bread, bagel, pastry from food sold on the streets, pastry from traditional cuisine, and baklava from deserts ${ }^{41,42}$. Ercan et al. ${ }^{42}$ found out that among 79 male and 11 female street food sellers the number of those thinking that food could be a source of disease was high. It was emphasized that there were differences among hygienic knowledge, attitude, and applications of street food sellers and that hygiene applications were not sufficient enough. However, there has not been a comprehensive study on this subject. Therefore, this study was planned and carried out in order to determine the street food preferences, the reasons for these preferences and effect of socio-demographic factors among young people.

\section{Methods}

\section{Research design}

The study was designed as a descriptive study. A sample consisted of 847 young volunteer consumers $($ male $=368$, female $=479)$ who were either high school (15-19 years old) or university students (above 19 years old). At the beginning of the study participating of total 1100 students (550 high school, 550 university) was targeted, but 325 high school and 522 university students accepted to participate the study (response rate: $77 \%$ ). The data of the study were collected with a self-administrable questionnaire developed by the researchers between February and April 2014 in Ankara, the capital of Turkey.

Participants were informed about the subject and purpose of the study. Each young person signed a voluntary participation form and filled in the questionnaire, which adhered to the principles of the Declaration of Helsinki (World Medical Association).

\section{Instrumentation}

The research data were collected through a questionnaire which was tested as a pilot study on 62 consumers and then suitable modifica- tions were made. The consumers in the survey were especially reminded that truthful information was required for the success of the study and that the information would be kept confidential. Students aged below 15 years and not consume street foods were excluded.

The questionnaire was organised into two main sections;

i) Demographic information;

ii) Consumers' decisions regarding street food preferences and preference causes.

\section{Demographic information}

The first section of the questionnaire was four questions related to gender, age, income, and educational background as the demographic information.

\section{Street food preferences}

The participants were asked to indicate their favorite fives ones from the list of 45 street foods mostly consumed in Turkey. And so on and so far for food safety knowledge; food purchase decisions; factors influencing food choices; concerns about food safety of street foods; attitudes towards food safety regarding street food. The factors influencing food choices were designed based on food choice questionnaires developed by other researchers ${ }^{43-46}$, including convenience, sensory appeal (appearance, taste, smell, texture, and sound), price, nutritional value, mood, familiarity, the appearance of street food, and safety. A five-point Likert scale, ranging from one (1) "strongly disagree" to five (5) "strongly agree" was also used to determine respondents' attitudes towards street food safety and the reasons for choosing street foods with 25 items. Each item score ranged between 1-5 and the total street food preference score obtained from this questions range between 25-125. Rising of the total score indicates that there are more causes for prefer street foods.

Questionnaires were modified and tested for suitability through Cronbach's alpha test with a reliability coefficient of 0.83 . The questionnaire took approximately 15 minutes to complete.

\section{Statistical analysis}

The SPSS Version 15.0 (SPSS Inc., Chicago, IL, USA) statistical software package was used for all analyses. The results were expressed as mean \pm standard deviations $( \pm S D)$, frequencies, and per- 
centages. Descriptive statistics were used to summarise the variables of interest and determine relationships between them. An independent $t$-test was applied for binary variables to compare the scores regarding street food preference according to gender, education level; age, and the frequency of consumption of street food, while a one-way ANOVA (confidence interval 95\%) was applied for more than two variables, and a post hoc LSD test was used to determine the group causing the difference. Statistical significance was identified at the $95 \%$ confidence interval $(p<0.001$ and $p<0.05)$.

\section{Results}

Eight hundred and forty-seven questionnaire forms were filled in by young consumers. Of the young respondents, $43.4 \%$ were male and $56.6 \%$ were female. Among the young consumers, $38.4 \%$ were between 15 and 18 years of age, $40 \%$ were between 19 and 22 years of age, and $21.6 \%$ were 23 years of age and over (Table 1 ).

The mean street food preference scores of males $(86.3 \pm 6.1)$ was found to be higher than females $(80.3 \pm 12.2)$ and the difference was statistically significant $(t=8.63, p<0.05)$. University students $(86.2 \pm 7.5)$ preferred consuming street foods more than high school students $(77.4 \pm 12.1)(t=13.06, p<0.05)$. The mean street food preference score $(87.5 \pm 4.6)$ was higher for 19-22 years old than for other age groups $(F=103.8, p<0.05)$. The differences between all age groups are also statistically significant $(p<0.05)$ (Table 1$)$.
Street foods frequently that are consumed in Turkey are shown in Table 2. In this study it was found that Turkish bagel ( $\mathrm{n}=511,60.33 \%)$, döner $(\mathrm{n}=371,43.80 \%)$, boiled corn in a cup $(\mathrm{n}=322,38.01 \%)$, and toast $(\mathrm{n}=319,37.66 \%)$ are the most preferred street foods among young people. Çiğ köfte, fried potatoes, pizza, and ice cream are frequently preferred foods.

The preference scores of participants who consume street foods 1-3 times a year were the lowest $(65.5 \pm 0.7)$ and those of participants who consume it daily $(85.4 \pm 9.07)$ were the highest. There was a statistically significant difference be-

Table 2. The most preferred street foods of young $(\mathrm{n}=847)$.

\begin{tabular}{lcc}
\hline \multicolumn{1}{c}{ Street Food } & n & (\%) \\
\hline Turkish bagels (pastries, etc.) & 511 & 60.33 \\
Döner & 371 & 43.80 \\
Boiled corn in a cup & 322 & 38.01 \\
Toast & 319 & 37.66 \\
Çiğ köfte & 290 & 34.23 \\
Fried potatoes & 256 & 30.22 \\
Pizza & 208 & 24.55 \\
Ice cream & 185 & 21.84 \\
Meatball sandwich & 154 & 18.18 \\
Kumpir (baked potato) & 153 & 18.06 \\
Gözleme (pancake) & 112 & 13.22 \\
Fried fish sandwich & 102 & 12.04 \\
Tantuni & 68 & 8.02 \\
Kokoreç (grilled sheep intestine) & 25 & 2.95 \\
\hline
\end{tabular}

Table 1. Street food preference scores of young's according to gender, education level and age (mean, standard deviation and significance level).

\begin{tabular}{|c|c|c|c|c|c|c|}
\hline Demographic characteristics & $\mathbf{n}$ & $(\%)$ & $\chi \pm S D$ & $\mathrm{t} / \mathrm{F}$ test & p value & Tukey test \\
\hline \multicolumn{7}{|l|}{ Gender } \\
\hline Male & 368 & $(43.4)$ & $86.3 \pm 6.1$ & $t=8.63$ & $0.000^{*}$ & \\
\hline Female & 479 & $(56.6)$ & $80.3 \pm 12.2$ & & & \\
\hline \multicolumn{7}{|l|}{ Education level } \\
\hline High school student & 325 & $(38.4)$ & $77.4 \pm 12.1$ & $t=13.06$ & $0.000^{*}$ & \\
\hline University student & 522 & $(61.6)$ & $86.2 \pm 7.5$ & & & \\
\hline \multicolumn{7}{|l|}{ Age (years) } \\
\hline $15-18$ years of age & 325 & $(38.4)$ & $77.4 \pm 12.1$ & $\mathrm{~F}=103.8$ & & \\
\hline $19-22$ years of age & 339 & $(40.0)$ & $87.5 \pm 4.6$ & & $0.000^{*}$ & $(1-2),(1-3),(3-2)$ \\
\hline $23+$ years of age & 183 & $(21.6)$ & $84.0 \pm 0.2$ & & & \\
\hline
\end{tabular}


tween preference scores according to consumption frequency $(F=6.96, p<0.05)$ (Table 3$)$.

A statistically significant correlation was found between the street food consumption preference score and education level $(\mathrm{r}=-0.169$, $\mathrm{p}=0.000)$, gender $(\mathrm{r}=-0.219, \mathrm{p}=0.000)$, and age $(\mathrm{r}=-0.138, \mathrm{p}=0.000)(\mathrm{p}<0.001)($ Table 4$)$.

It was shown that although the young consumers knew that it is easier for street food to contaminate people with microorganisms $(M=3.46 \pm 0.96, F=3.15 \pm 1.08)$, vendors paid no attention to hygiene $(M=2.31 \pm 0.83$, $F=2.60 \pm 1.02)$, street foods are raw or not cooked well $(M=2.44 \pm 0.49, F=2.67 \pm 0.60)$, and consumers preferred this food because of its cheapness $(M=4.22 \pm 0.78, F=3.61 \pm 1.13)$, the satisfaction it gives $(M=3.91 \pm 0.89$, $F=3.32 \pm 1.20)$, its taste $(M=4.03 \pm 0.83$, $F=3.89 \pm 0.96)$, its variety $(M=3.07 \pm 0.76$, $F=3.54 \pm 0.85)$, its fast service $(M=4.41 \pm 0.73$, $F=3.69 \pm 1.10)$, and because it is consumed by most people $(M=4.33 \pm 0.63, F=3.99 \pm 1.08)$. The difference in the mean scores between the genders is statistically significant $(p<0.05)$ (Table 5).

\section{Discussion}

Street foods are widely consumed and produced in almost all countries around the world, as a result of nutritional trends in urban areas ${ }^{47}$. Street food is preferred by consumers, especially students, because of its delicious taste, accessibility, variety, and cheapness ${ }^{14}$.

Most studies have found that street food is adequate in terms of cleanliness, hygiene, and quality $^{12,15-23}$. Şanlier ${ }^{48}$ reported that the food safety knowledge scores and safe food preparation practice scores of young consumers were lower than adults. Sert and Kapusuz ${ }^{49}$ found in their study that $75 \%$ of participants preferred street food occasionally and $18.9 \%$ usually. In the present study, while the street food consumption preference scores were low in participants who consumed street foods 1-3 times a year, they was high in participants who consumed it daily $(F=6.96, p=0.000)$ (Table 3$)$. In a study the most preferred foods were pastries, Turkish bagels, fried potatoes, toast, hamburgers, and doner ${ }^{50}$. In the present study the most preferred foods were Turkish bagels $(\mathrm{n}=511,60.33 \%)$, döner $(\mathrm{n}=371,43.80 \%)$, boiled corn in a cup $(\mathrm{n}=322,38.01 \%)$, and toast $(\mathrm{n}=319,37.66 \%)$ (Table 2). The preferred street foods were simi-
Table 3. Young's preference scores according to consumption frequency of street foods.

\begin{tabular}{lrrrrr}
\hline $\begin{array}{c}\text { Consumption } \\
\text { frequency }\end{array}$ & $\mathbf{n}(\%)$ & \multicolumn{1}{c}{$\boldsymbol{\chi} \pm$ SD } & $\mathbf{F}$ & $\begin{array}{c}\mathbf{p} \\
\text { value }\end{array}$ \\
\hline Daily & 197 & $(23.3)$ & $85.4 \pm 9.07$ & 6.96 & $0.000^{*}$ \\
2-3 times per week & 340 & $(40.1)$ & $83.6 \pm 10.06$ & & \\
Weekly & 190 & $(22.4)$ & $81.2 \pm 11.3$ & & \\
2 times per month & 59 & $(7.0)$ & $79.5 \pm 9.4$ & & \\
Monthly & 50 & $(5.9)$ & $78.2 \pm 8.8$ & & \\
1-3 times a year & 11 & $(1.3)$ & $65.5 \pm 0.7$ & & \\
\hline
\end{tabular}

${ }^{*} \mathrm{p}<0.001$.

Table 4. Correlation between gender, age, education level and preference scores of street foods (r).

\begin{tabular}{lcc}
\hline & $\begin{array}{c}\text { Consumption preference } \\
\text { score }(\mathbf{r})\end{array}$ & p value \\
\hline Gender & $-0.219^{*}$ & $0.000^{\star}$ \\
Age (year) & $-0.138^{*}$ & $0.000^{*}$ \\
Education level & $-0.169^{*}$ & $0.000^{\star}$ \\
${ }^{*} \mathrm{p}<0.001$. & &
\end{tabular}

lar in these two studies. In another study it was determined that people preferred hamburgers, pizza, fried potatoes, and meat products ${ }^{51}$. As a result, easy accessibility, cheapness, traditional, variety, fast service, practice and delicious specifications of street foods effect consumers' preferences. But it is also known that these foods threaten consumers' health because of poor hygiene conditions. Because of cross-contamination risk and lack of legal regulations for safety precautions for consumers has a negative effect on public health. So legal obligations on street foods and vendors and self-controlled practice and behaviours of vendors are effective in prevention of consumers' health.

In one study, students consumed street foods quite frequently because of their economic and fast service considerations, although they knew that these foods are unhealthy and have low nutritional value ${ }^{49}$. Similarly, in the present study although street food was widely consumed, the scores of preference causes "clean and suitable for health" and "healthy" were low. The difference according to gender was statistically significant ( $p=0.000$ ) (Table 5 ). This may be due to living away from their families for education and having not enough time to preparing 
Table 5. The street foods preference scores according to gender ( \pm SD).

\begin{tabular}{|c|c|c|c|c|}
\hline Preference causes of street foods & $\begin{array}{l}\text { Male }(n=368) \\
\quad \chi \pm S D\end{array}$ & $\begin{array}{l}\text { Female }(n=479) \\
\chi \pm S D\end{array}$ & $t$-test & $p$-value \\
\hline Cheap & $4.22 \pm 0.78$ & $3.61 \pm 1.13$ & 8.92 & $0.000^{\star *}$ \\
\hline Tasty & $4.03 \pm 0.83$ & $3.89 \pm 0.96$ & 2.18 & $0.029^{*}$ \\
\hline Healthy & $1.90 \pm 0.82$ & $2.21 \pm 0.91$ & 5.00 & $0.000^{\star *}$ \\
\hline Fast consumption & $4.13 \pm 0.83$ & $3.36 \pm 1.17$ & 10.75 & $0.000^{\star *}$ \\
\hline Clean and suitable for health & $2.15 \pm 0.63$ & $2.39 \pm 1.02$ & 3.86 & $0.000^{\star *}$ \\
\hline More satisfying & $3.91 \pm 0.89$ & $3.32 \pm 1.20$ & 7.86 & $0.000^{* *}$ \\
\hline Fast service & $4.41 \pm 0.73$ & $3.69 \pm 1.10$ & 10.77 & $0.000^{* *}$ \\
\hline Consumed by most people & $4.33 \pm 0.63$ & $3.99 \pm 1.08$ & 5.34 & $0.000^{\star *}$ \\
\hline Easily accessible & $4.52 \pm 0.61$ & $4.12 \pm 0.86$ & 7.63 & $0.000^{\star *}$ \\
\hline Sold legally & $4.32 \pm 0.73$ & $3.67 \pm 1.12$ & 9.63 & $0.000^{\star *}$ \\
\hline Familiar vendor & $3.19 \pm 0.84$ & $2.38 \pm 0.94$ & 12.92 & $0.000^{\star *}$ \\
\hline Vendors pay attention to hygiene & $2.31 \pm 0.83$ & $2.60 \pm 1.02$ & 4.41 & $0.000^{\star *}$ \\
\hline Vendors are helpful & $3.28 \pm 0.77$ & $2.78 \pm 0.97$ & 8.06 & $0.000^{* *}$ \\
\hline Vendors are full of sweetness and light & $3.60 \pm 0.81$ & $2.73 \pm 1.13$ & 12.38 & $0.000^{\star *}$ \\
\hline Vendors show more interest & $3.26 \pm 0.67$ & $2.92 \pm 0.91$ & 5.97 & $0.000^{\star *}$ \\
\hline Food preparation can be seen & $3.75 \pm 1.02$ & $3.28 \pm 1.13$ & 6.21 & $0.000^{\star *}$ \\
\hline Foods appeal to the taste buds & $3.50 \pm 0.66$ & $3.64 \pm 0.99$ & 2.29 & $0.02^{\star}$ \\
\hline Low nutritional value & $3.06 \pm 0.84$ & $2.92 \pm 0.87$ & 2.39 & 0.17 \\
\hline Satisfies hunger & $4.18 \pm 0.78$ & $3.97 \pm 0.94$ & 3.43 & $0.001^{\star}$ \\
\hline Reflects food culture & $2.38 \pm 0.73$ & $2.87 \pm 1.16$ & 7.05 & $0.000^{\star *}$ \\
\hline $\begin{array}{l}\text { Increases chances of Contamination with } \\
\text { microorganisms }\end{array}$ & $3.46 \pm 0.96$ & $3.15 \pm 1.08$ & 4.20 & $0.000^{\star *}$ \\
\hline Raw and not cooked well & $2.44 \pm 0.49$ & $2.67 \pm 0.60$ & 5.77 & $0.000^{* *}$ \\
\hline Variety & $3.07 \pm 0.76$ & $3.54 \pm 0.85$ & 8.18 & $0.000^{* *}$ \\
\hline Consume much more & $4.10 \pm 0.67$ & $3.86 \pm 0.89$ & 4.33 & $0.000^{\star *}$ \\
\hline Easy to consume with family & $2.64 \pm 0.79$ & $2.60 \pm 1.04$ & 0.65 & 0.51 \\
\hline Total score & $86.27 \pm 6.13$ & $80.26 \pm 12.21$ & 8.64 & $0.000^{\star *}$ \\
\hline
\end{tabular}

${ }^{*} p<0.05 ;{ }^{* *} p<0.001$.

foods because of education system consists a lot of exams in Turkey.

In various studies street foods were frequently preferred because they offer delicious varieties of tastes, are cheap and satisfying, easily accessible, have an important role in the preservation of cultural and social inheritance, and are freshly prepared ${ }^{2,30,35,52}$. Similarly, in this study the scores of preference causes "more satisfying", "variety", "easily accessible", "food preparation can be seen", and "reflects food culture" were high. The difference between the genders was significant $(p=0.000)$ (Table 5). This can arise from that males prefer eating outside more than females.

Silva et al. ${ }^{52}$ found that $22.6 \%$ of vendors stated that they do not disinfect their hands while they are working and $80.2 \%$ touch food and money at the same time. In another study, only $30-37 \%$ of vendors were aware of the hygiene practices in food processing and $8-11 \%$ of vendors did not have any information about food contamination'. Rahman et al. ${ }^{53}$ stated in their study that vendors had inadequate information about food safety attitudes and practices and that there are problematic practices. Liu et al..$^{54}$ showed that the ratio of foodborne diseases caused by Vibrio parahaemolyticus in street foods was high. In India, $70 \%$ of 60 samples taken from street vendors were contaminated with $E$. coli and S. typhimurium and the necessity of hygiene control and enhancing the microbial quality of the food was emphasised ${ }^{55}$. Samapundo et al. ${ }^{4}$ determined that consumers and vendors have an intermediate level of food safety knowledge and attitudes. As street foods are consumed quite often, the necessity of educating both vendors and consumers about food hygiene must be 
considered. Successful food hygiene education and knowledge about food hygiene practices due to this education are important in the prevention of foodborne diseases around the world. In a study conducted in India, it was determined that after educating 80 vendors about food safety and hygiene, the mean knowledge level was raised from $24.35 \%$ to $66.2 \%$ and that the adaptation of good hygiene practices was raised from $37.5 \%$ to $50.8 \%{ }^{9}$, indicating that food hygiene education can affect consumers' and vendors' behaviour positively. In nutrition programmes in the USA, students are taught about food hygiene and safe food selection in addition to their nutritional behaviour being observed in order to provide them with healthy nutrition ${ }^{56}$. Therefore, by educating high school and university students about the importance of food safety, the risk of foodborne diseases can be reduced.

There is a general perception that street foods are unsafety. Also vendors are generally unlicensed, and uneducated about food hygiene and sanitation practice and working in unhygienic conditions so these results with rising consumers' doubts. Educating vendors in personal hygiene and good manufacture practice can minimize pathogen contamination risk for consumers. In addition consumers determine the quality of food-related audits and inspections performed by the government to protect people. Consumers, through non-governmental organisations established by them, prompt the government to lay down rules that are aimed at protecting consumer rights and ensuring proper food safety. Although food safety is handled by the government, the food industry, and consumers, the government has the primary responsibility due to its power to enact food-oriented rules and directives ${ }^{57}$.
The first step towards determining the measures that need to be taken and conducting a risk analysis of food safety should be to educate consumers on food safety. An effective food safety education programme should cover information concerning the temperature control of food, proper food preparation practices, the prevention of cross contamination, suitable cleaning and disposal procedures, causative agents of foodborne illnesses, high-risk groups, and other contributing factors to foodborne diseases and prevention strategies ${ }^{58}$. However, means should be provided to help disseminate the messages that any food safety education programme would deliver to consumers. To raise consumers' food safety knowledge and awareness about street food, we suggest targeted media information and materials on good hygiene practices in the form of brochures and leaflets for all ages. Consumers could receive these materials after short education/training programmes and the materials could be enhanced by including statements from reliable sources.

\section{Limitations}

As the population of this study consisted of young consumers from central Turkey, the results cannot be generalised for all consumers or all ages. Performing the study on a large sample of consumers of all ages would be useful. Although the reliability coefficient found was high, interpretation of the results is limited due to responses being self-reported, which are prone to subject bias. Instrument validation for all ages of consumers through more testing and observational studies is needed. 


\section{Collaborations}

$\mathrm{N}$ Sanlier was responsible for the conception and development of the study, data analysis and interpretation, writing of the manuscript and critical review of the content. AC Sezgin participated in the design of the study and helped to draft the manuscript. G Sahin participated in the design of the study, performed the statistical analysis and helped to draft the manuscript E Yassibas participated in the design of the study, performed the statistical analysis and helped to draft the manuscript. All authors read and approved the final manuscript to be published.

\section{Acknowledgements}

The authors would like to thank the young consumers who agreed to participate in the study and answered the questions truthfully and wholeheartedly for their cooperation.

\section{References}

1. Ben F. World of Consumption: The Material and Cultural Revisited. $2^{\text {nd }}$ edition. London, New York: Routledge; 2002.

2. Chukuezi CO. Food safety and hyienic practices of street food vendors in Owerri, Nigeria. Studies in Sociology of Science 2005; 1(1):50-57.

3. Food and Agriculture Organization of the United Nations (FAO). INFOSAN Information Note No. 3/2010-Safety of street vended food. [website on the Internet]. 2010 [accessed 2015 Jul 09]. Available at: http://www.who.int/foodsafety/fs_management/ No_03_StreetFood_Jun10_en.pdf.

4. Samapundo S, Climat R, Xhaferi R, Devlieghere F. Food safety knowledge, attitudes and practices of street food vendors and consumers in Port-au-Prince, Haiti. Food Control 2015; 50:457-466.

5. Ackah M, Gyamfi ET, Anim AK, Osei J, Hansen JK, Agyemang O. Socio-economic profile, knowledge of hygiene and food safety practices among street-food vendors in some parts of Accra-Ghana. Internet Journal of Food Safety 2011; 13:191-197.

6. Food and Agriculture Organization of the United Nations (FAO). The place of urban and peri-urban agriculture (UPA) in national food security programmes. Rome:Technical Cooperation Dept; 2011.

7. Muzaffar AT, Huq I, Mallik BA. Entrepreneurs of the streets: an analytical work on the street food vendors of Dhaka City. International Journal of Business and Management 2009; 4(2):80-88.

8. Food and Agriculture Organization of the United Nations (FAO). Food for the cities: Street foods. [website on the Internet]. 2013 [accessed 2015 Nov 12] Available at: http://www.fao.org/fcit/food-processing/street-foods/ en/.

9. Choudhury M, Mahanta LB, Goswami JS, Mazumder MD. Will capacity building training interventions given to street food vendors give us safer food?: A cross-sectional study from India. Food Control 2011; 22(8):1233-1239.

10. Fellows P, Hilmi M. Selling street and snack foods. FAO Diversification Booklet 18. Rural Infrastructure and Agro-Industries Division. Rome: Food and Agriculture Organization of the United Nations. [booklet on the Internet]. 2011 [accessed 2015 Jul 23] Available at: http://fao.org/docrep/015.

11. Canet C, N'Diaye, C. Street foods in Africa. Food Nutrition and Agriculture 1996; 17/18:4-13.

12. Lucca A, Torres EAFS. Street-food: the hygiene conditions of hot-dogs sold in São Paulo, Brazil. Food Control 2006; 17(4):312-316.

13. Muinde OK, Kuria E. 2005. Hygienic and sanitary practices of vendors of street foods in Nairobi, Kenya. African Journal of Food Agriculture and Nutritional Development (AJFAND) 2005; 5(1):1-14.

14. World Health Organization (WHO). Basic steps to improve safety of street-vended food. International Food Safety Authorities Network (INFOSAN), Information Note No.3/2010 - Safety of street-vended food. [website on the Internet]. 2010 [accessed 2015 Aug 08] Available at: http://www.who.int/foodsafety/fs_management/No_03_StreetFoodJun10_en.pdf 
15. Abdallah M., Mustafa NEM. Bacteriological quality of street-vended Um-Jinger: a traditional Sudanese food. Internet Journal of Food Safety 2010; 12:16-19.

16. Biswas S, Parvez MAK, Shafiquzzaman M, Nahar S, Rahman. MN. Isolation and characterization of Escherichia coli in ready-to-eat foods vended in Islamic University, Kushtia. Journal of Bio-Science 2010; 18(1):99103.

17. Edema MO, Omemu AM. Microbiology and food hygiene in public food services. Proceedings of the International Conference on Science and National Development held at University of Agriculture, 2004 Oct 25-28, Abeokuta.

18. Haryani Y, Tunung R, Chai LC, Lee HY, Tang SY, Son R. Characterization of Enterobacter cloacae isolated from street Foods. ASEAN Food Journal 2008; 15(1):57-64.

19. Mahale DP, Khade RG, Vaidya VK. Microbiological analysis of street vended fruit juices from Mumbai city, India. Internet Journal of Food Safety 2008; 10:31-34.

20. Mamun MA, Rahman M, Turin TC. Microbiological quality of selected street food items vended by schoolbased street food vendors in Dhaka, Bangladesh. International Journal of Food Microbiology 2013; 166(3):413418.

21. Nunes BN, Cruz AG, Faria JAF, Anderson SSA, Silva R, Moura MRL. A survey on the sanitary condition of commercial foods of plant origin sold in Brazil. Food Control 2010; 21(1):50-54.

22. Omemu AM, Edema MO, Bankole MO. Bacteriological assessment of street vended ready to eat (RTE) vegetables and prepacked salad in Nigeria. Nigerian Journal of Microbiology 2005; 19(1-2):497-504.

23. Omemu AM, Aderoju ST. Food safety knowledge and practices of street food vendors in the city of Abeokuta, Nigeria. Food Control 2008; 19(4):396-402.

24. Barro N, Bello AR, Itsiembou Y, Savadogo A, Owattara CAT, Nikiema P, De SC, Traore AS. Street vended foods improvement: contamination mechanism and application of food safety objective strategy: Critical Review. Pakistan Journal of Nutrition 2007; 6(1):1-10.

25. Egan MB, Raats MM, Grubb SM, Eves A, Lumbers ML Dean MS, Adams MR. A review of food safety and food hygiene training studies in the commercial sector. Food Control 2007; 18:1180-1190.

26. Pilling VK, Brannon LA, Shanklin CW, Howells AD, Roberts KR. Identifying specific beliefs to target to improve restaurant employees' intentions for performing three important food safety behaviours. Journal of the American Dietetic Association, 2008; 108:991-997.

27. Khairuzzaman MD, Chowdhury FM, Zaman S, Mamun A, Bari MDL. Food Safety challenges towards safe, healthy, and nutritious street foods in Bangladesh. Hindawi Publishing Corporation International Journal of Food Science, 2014; Article ID 483519.

28. Ghosh M, Wahi S, Ganguli KM. Prevalence of enterotoxigenic Staphylococcus aureus and Shigella spp. in some raw street vended Indian foods. International Journal of Environmental Health Research 2007; 17(2):151-156.

29. Gordon-Davis L. The hospitality industry handbook on hygiene and safety for South African Students and Practioners. Johannesburg: Juta and Company Ltd; 2011.
30. Hanashiro A, Morita M, Matte GR, Matte MH, Torres EAFS. Microbiological quality of selected street foods from a restricted area of Sao Paulo City, Brazil. Food Control 2005; 16(5):439-444.

31. Teague NS, Srijan A, Wongstitwilairoong B, Poramathikul K, Champathai T, Ruksasiri S, Pavlin J, Mason CJ. Enteric pathogen sampling of tourist restaurants in Bangkok, Thailand. Journal of Travel Medicine 2010; 17(2):118-123.

32. Schlundt J, Toyofuku H, Jansen J, Herbst SA. Emerging Food-Borne Zoonoses. Review of Science and Techno$\log y 2004 ; 23: 513-515$

33. Rane S. Street Vended Food in Developing World: Hazard Analyses. Indian J Microbiol 2011; 51(1):100-106.

34. Turkey. Ministry of Health. Basic Health Statistics of Turkey 2004, 142. Ankara: Ministry of Health Publications; 2006

35. Aluko OO, Ojeremi TT, Olakele DA, Ajidagba EB. Evaluation of food safety and sanitary practices among food vendors at car parks in Ile Ife, southwestern Nigeria. Food Control 2014; 40:165-171.

36. Oguntona CRB, Kanye O. Contribution of street foods to nutrient intakes by Nigerian adolescents. Nutrition Health 1995; 10:165-171.

37. Oguntona CRB, Tella TO. Street foods and dietary intakes of Nigerian urban market women. International Journal of Food Sciences and Nutrition 1999; 50:383390.

38. Steyn D, Labadarios L, Nel J. Factors which influence the consumption of street foods and fast foods in South Africa-a national survey. Nutrition Journal 2011; 10:2-10.

39. Güven K, Benlikaya N. Acid produced by lactic acid bacteria prevent the growth of Bacillus cereus in Boza, a traditional fermented Turkish beverage. Journal of Food Safety 2005; 25:98-108.

40. Temelli S, Saltan Evrensel S, Anar Ş, Tayar M. Determination of microbiological quality of kokoreç samples consumed in Bursa. Journal Faculty of Veterinary Medicine of Istanbul University 2002; 28(2):467-473.

41. Sormaz Ü, Sürücüoğlu MS, Akan LS. Beslenme Kültüründeki Eğilim Fast Food Yemek Tercihleri. 38. ICANAS Kongresi. (10-15 Eylül 2007/Ankara): Bildiriler Maddi Kültür III. Cilt. Atatürk Kültür, Dil ve Tarih Yüksek Kurumu Yayınları:4/3. 2008; 1211-1231, Korza Yayıncılık Basım San. ve Tic. Ltd. Sti. Ankara.

42. Ercan A, Ekizoğlu Ş, Kızıltan G. Ankara ve İstanbul'daki Sokak Gıda Satıcilarının Hijyen Bilgi ve Uygulamalarının Karşılaştırılması. Türkiye 11. Gıda Kongresi Özet Bildiri Kitabı, 2012; page: 260. 10-12 Ekim 2012, Mustafa Kemal Üniversitesi, Hatay.

43. Ansari-Lari M, Soodbakhsh S, Lakzadeh L. Knowledge, attitudes and practices of workers on food hygienic practices in meat processing plants in Fars, Iran. Food Control 2010; 21(3):260-263.

44. Bolton DJ, Meally A, Blair IS, Mcdowell DA, Cowan C. Food safety knowledge of head chefs and catering managers in Ireland. Food Control 2008; 19(3):291-300.

45. Kim HY, Lim YI, Kim HJ. A study on the ready-to-eat street foods usage of customers in a college-town in Northern part of Seoul. Journal of the Korean Society of Food Culture 2007; 22(1):43-57. 
46. Kiwoong C, Sanghyun P, Nami J. Study on a model of street vended food choices by Korean high school students. Nutrition Research and Practice 2011; 5(5):481488.

47. Draper A. Street foods in developing countries: the potential for micronutrient fortification. London School of Hygiene and Tropical Medicine 1996; 1-66.

48. Şanlıer N. The knowledge and practice of food safety by young and adult consumers. Food Control 2009; 20(6):538-542.

49. Sert S, Kapusuz F. Street foods: research on students' opinions and reasons for preferring. Electronic Journal of Food Technologies 2010; 5(3):25-35.

50. Özçelik AÖ, Sürücüoğlu MS. Fast food preferences of the consumers. Food 1998; 23(6):437-447.

51. Hamşığlu AB. An application on determining the life-style of consumers who consume fast-food products. International Journal of Economic and Administrative Studies 2013; 6(11):17-34.

52. Silva SA, Cardoso RCV, Góes JAW, Santos JN, Ramos FP, Jesus RB, Vale RS, Silva PST. Street food on the coast of Salvador, Bahia, Brazil: A study from the socioeconomic and food safety perspectives. Food Control 2014; 40:78-84.

53. Rahman M, Taha Arif M, Bakar K, Tambi Z. Food safety knowledge, attitude and hygiene practices among the street food vendors in Northern Kuching City, Sarawak. Borneo Science 2012; 31:95-103.

54. Liu S, Liu Z, Zhang H, Lu L, Liang J, Huang Q. Knowledge, attitude and practices of food safety amongst food handlers in the coastal resort of Guangdong, China. Food Control 2015; 47:457-461.

55. Garode AM, Waghode SM. Bacteriological status of street-vended foods and public health significance: a case study of Buldana District, MS, India. ISCA Journal of Biological Sciences 2012; 1(3):69-71.

56. Robertson C. Safety, nutrition and health in early education. New York: Delmar Publishers; 2014.

57. Soydal F. Food safety, risk assessment. Journal of Food 1999; 7:63-65.

58. Osaili TM, Obeidat BA, Jamous DOA, Bawadi HA. Food safety knowledge and practices among college female students in north of Jordan. Food Control 2011; 22(2):269-276.

Artigo apresentado em 15/03/2016

Aprovado em 01/08/2016

Versão final apresentada em 03/08/2016 